\title{
On AN EnCounter of Two Men of MAthematics in LiMA
}

\author{
To MaURício M. PEIXoto, 1921 - 2019, AND José TOLA PASQUEL, 1914 - 1999, IN MEMORIAM. \\ Jorge Sotomayor \\ Universidade de São Paulo - USP - Brasil \\ (aceito para publicação em agosto de 2020)
}

\begin{abstract}
This evocative essay focuses on the encounter of two eminent Men of Mathematics: José Tola Pasquel, Peruvian, and Maurício Matos Peixoto, Brazilian, in November of 1961 in Lima. It glimpses into the local meaning and later mathematical consequences of such apparently random event. Here are discussed its implications for the participation of the author in the starting steps of the Qualitative Theory of Differential Equations, earlier name for Dynamical Systems, as a research activity in Brazil.
\end{abstract}

Keywords: Mathematics, History, Differential Equations, Dynamical Systems, Peixoto, Tola.

\section{[SOBRE UM ENCONTRO DE DOIS HOMENS DA MATEMÁTICA EM LIMA]}

\section{Resumo}

O presente ensaio evocativo relata o encontro entre dois eminentes Homens da Matemática: José Tola Pasquel, peruano, e Maurício Matos Peixoto, brasileiro, realizado em novembro de 1961, em Lima. O significado local e as consequências matemáticas desse encontro são aqui analisados. Tal análise conduz a uma reflexão sobre o papel desempenhado por tal evento, aparentemente aleatório, na participação do autor na etapa inicial, como área de pesquisa no Brasil, da Teoria Qualitativa das Equações Diferenciais, atualmente denominada Sistemas Dinâmicos.

Palavras-chave: Matemática, História, Equações Diferenciais, Sistemas Dinâmicos, Peixoto, Tola. 


\section{An auspicious overnight stay in Lima.}

Two Men of Mathematics, quite special in their own accomplishments and countries: José Tola Pasquel (Tola), 1914-1999, Peruvian, and Maurício Matos Peixoto (Peixoto), 19212019, Brazilian, met in Lima in November 1961.

Besides the occasion for mathematical social contact, Tola's leitmotif for the encounter was to inquire Peixoto about the possibility of obtaining a scholarship from the (now National) Institute of Pure and Applied Mathematics (IMPA), at which Peixoto was Chief Researcher, for a student of his, Jorge Sotomayor (b. 1942), author of this essay, then finishing the third year in the School of Mathematics of San Marcos University. Tola was recommending me for a scholarship to participate in an academic stage at IMPA in the year of 1962.

Peixoto was well aware of the situation and had agreed to meet Tola, and thus, to get a closer view into his inquiry. He had been persuaded to do that by his IMPA colleague Leopoldo Nachbin (Nachbin), 1922-1993.

In the sixties Peixoto and Nachbin, two of the founders of IMPA in 1952, were among the best known mature Brazilian mathematicians. Great expectations for the future of Brazilian Mathematics were deposited on their shoulders.

Nachbin, had met Tola in previous occasions and knew of his preponderance for Peruvian mathematics. To him, Tola had addressed a letter on the aforementioned inquiry.

This was the third attempt of Tola on his endeavor to make 1962 a stimulating mathematical year for me. The first one had been through a letter written to the Director of the Institute of Mathematics in Buenos Aires. The letter, however, was either lost in the mail or disregarded by the addressee. Fortunately, the second letter was promptly answered by Nachbin, bringing into the panorama the name of Peixoto. In that letter, Nachbin announced that he would be on leave of absence, away from Brazil, and that could not be able to supervise students in 1962. He then suggested the name of Peixoto as an auspicious possibility. He added that, coincidentally, in a couple of weeks, Peixoto's flight, from Rio de Janeiro to Washington, would stop overnight in Lima for refueling. Thus, Peixoto would be staying for a single night in Lima, what seemed to be a providential occasion for the meeting.

The facts had unfolded rapidly: Tola's project, outlined for me had been brought into the attention of two of the most prestigious Brazilian mathematicians of the sixties.

The eminence of the three men involved in the project and their respective crucial roles for Peruvian and Brazilian Mathematics is well documented. The following Wikipedia pages give an initial idea:

Tola: https://es.wikipedia.org/wiki/Jos\%C3\%A9_Tola_Pasquel. See also SOTOMAYOR 2020-3.

Peixoto: https://pt.wikipedia.org/wiki/Maur\%C3\%Adcio_Peixoto, See subsection 4.4.

Nachbin: https://pt.wikipedia.org/wiki/Leopoldo_Nachbin, See also PEREIRA. 


\section{A tightly scheduled dinner meeting.}

The fancy restaurant located at the Sky Room of the emblematic Crillon Hotel ${ }^{1}$, where the passengers of Peixoto's flight were lodged, was the scenario for the occasion of the encounter.

The ice, if any at all between the dinner partners, was soon melted by a round of Pisco Sours, ordered by Tola. He started the conversation by recounting what he considered a serious setback for Peruvian Mathematics derived by the recent elimination of the Mathematics Institute in San Marcos. The Institute had been absorbed, and dissolved, into a larger Faculty. He was quite disappointed by the fact that the changes had been consummated while he was on leave of absence.

Then, he talked about my case and the convenience that, at that moment, I could continue my studies in a center of excellence. He reputed that the fourth year of Mathematics in San Marcos 1962, would be a boring waste of time for any young man eager to learn stimulating mathematics.

Peixoto, who had been listening attentively, said:

"Maybe your young fellow could be integrated into the working group on the Qualitative Theory of Differential Equations that I will start next year at IMPA. However, I am worried by the fact that he will not yet be graduated".

Then they discussed various issues. Tola talked about his mentor Alfred Rosenblatt, Krakow 1880 - Lima 1947, the first great professional mathematician to reach San Marcos, where he left a remarkable influence, establishing there contemporary mathematical subjects in teaching and research. See https://es.wikipedia.org/wiki/ Alfred_Rosenblatt and CIECIELSKA.

Peixoto recounted how he had discovered the reef of Structural Stability in the works of the Russian mathematicians Andronov and Pontrjagin, through the presentation of DeBaggis, and how, subsequently, he had met the great mathematician Solomon Lefschetz (1884 - 1972), who had also played an important role in the development of his field of research. See the essay SOTOMAYOR 2020-2.

In the farewell after the meal and coffee, Peixoto said: "I intend to recommend your student to the Director of IMPA for a scholarship. I suggest that he sends me a letter of self introduction with a description of his mathematical level".

The day after, Tola communicated to me that my best option would be to go to Rio de Janeiro, to study Differential Equations at IMPA under the supervision of Prof. Maurício M. Peixoto. He said: "It is a very important area; furthermore, the Brazilian Professor is a great expert in that field. We have to benefit from this opportunity to update our scenario and develop it in our country. I am very optimistic about it".

The first step would be to write a letter to Peixoto in the above terms. I promptly mailed him the following letter, SOTOMAYOR 2018:

\footnotetext{
${ }^{1}$ Closed as a Hotel in 1999. Presently the building hosts numerous business offices.
} 
Prof. Maurício Peixoto

Research Institute for Advanced Study (RIAS)

Baltimore, Maryland, USA

Dear Prof. Peixoto,

My name is Jorge Sotomayor. I write following the advice of my teacher, Prof. José Tola, who has mentioned to you my interest in pursuing advanced mathematical studies in Brazil. He has told me of your request that I send you a report on my mathematical education, indicating, as much as possible, the level of knowledge that I have attained so far.

Presently I am finishing the third year at the Institute of Mathematics of San Marcos University, Lima. In December I will have finished Mathematical Analysis (a two-year course, which covers most of the book by APOSTOL). The same for Differential Geometry (a year course, which covers almost completely the book of WILLMORE) and Analytic Functions (a one-semester course, based on the book of AHLFORS and notes by Prof. Tola). Last semester I took a course on Modern Algebra, also taught by Tola, based on parts of van der WAERDEN and local lecture notes.

I mention only the courses to which I have devoted special attention, and in which I feel somewhat confident and fulfilled. I particularly enjoy the books of Apostol and Willmore and have worked a lot on them.

So far I have remained unaware of the theoretical aspects of Differential Equations, having taken last year, only a one-semester course on methods of solutions of ordinary ones. No other courses on ODEs or PDEs are taught here.

J. S.

\section{The letter from Peixoto and the scholarship, SOTOMAYOR 2018.}

Dear Sotomayor,

Next year, toward April, I will start at IMPA a series of courses and seminars on the Qualitative Theory of Differential Equations. In order that you may have a chance to catch up with the level of the other prospective participants, I suggest you do the following reading:

On Differential Equations: study CODDINGTON and Levinson, Chapters 1, 3, 15 and 16. You might find more accessible the little book by HUREWICZ, whose contents almost coincide with the material listed above.

On Topology: read SEIFERT and Threlfall; you should try to reach Homology, the structure of surfaces, and the Euler Characteristic on manifolds. The little book by PONTRYAGIN is also suitable for this matter.

I am writing now to Dr. Lélio Gama, Director of IMPA, recommending you for a fellowship. You will hear directly from him later.

M. P. 
Soon after that, I also received a very kind letter from Dr. Lélio Gama, Director of IMPA, offering me a scholarship for a one-year stay at IMPA.

With considerable struggle on my part, my mathematical preparation for the trip to Brazil lasted from December 1961 to mid-March 1962.

The outcome of this endeavor was the awareness of the existence of a Theory of Differential Equations founded, not only in Calculus, but in Mathematical Analysis and in Geometry. The Poincaré - Bendixson Theorem was a remarkable sample.

This initial sensation led me to fancy the idea that matters of great interest could be dwelling inside such Theory.

The generosity of Peixoto, in admitting me into his prospective study group, and the remarkable gesture of solidarity of IMPA, in granting me the scholarship, and one of the coveted seats in the flight Lima-Rio of the Brazilian Air Force (obtained by presenting a persuasive letter of recommendation from Dr. Lélio Gama to the Brazilian Consulate), made possible my arrival to Rio de Janeiro on March 28, 1962. The Seminar on the Qualitative Theory of Differential Equations, started on the first Saturday of April. At that time, I was endowed with a solid faith in books and had the naive belief that, by choosing them with good judgment, the gaps (or abysses) that separated me from higher mathematical knowledge and research, could be bypassed.

\section{Closing Comments.}

4.1. Several auspicious events (recounted in SOTOMAYOR 1992) led me, in 1959, to the only place in Peru where one could learn the basics of Real and Complex Mathematical Analysis, The Theory of Equations, Modern Algebra and Differential Geometry. See the essays SOTOMAYOR 1992 and SOTOMAYOR 2020-3. There, I could meet Prof. Tola. In the essay SOTOMAYOR 2018, I further elaborated the subject of "Encounters with Men of Mathematics".

In November 1961, with a hit of good luck, the hand of fate put Peixoto in contact with Tola, at the Crillon Hotel in Lima. There, with a toast of foaming Pisco Sour, they outlined, for me, a mathematical path to follow.

4.2. For a long while I carried in my briefcase the thoughtful letter of Peixoto. See Sec. 3. It was pregnant with mathematical meaning and energy. It induced me to glimpse into the connections of Differential Equations with Topology and later with Geometry.

The arduous reading preparation in the summer of 1962, following the list of topics in the letter, influenced my future mathematical apprenticeship during several years.

4.3. The sequence of favorable events exposed in the present essay propitiated to me the unique opportunity to eagerly follow Peixoto's Seminar along 1962, the year that his paper on Structural Stability PEIXOTO, a breakthrough in the core of Dynamical Systems, was published.

In 1963, with the support of Peixoto, my IMPA scholarship was renewed. This allowed me to engage in research problems stemming from Peixoto Seminar, an endeavor 
which converged to a doctoral thesis presented in 1964. See SOTOMAYOR 2019-2 and SOTOMAYOR 2020-3.

4.4. With some overlapping, this essay links the following related ones:

- A few words on Maurício M. Peixoto on his 80 ${ }^{\text {th }}$ birthday, SOTOMAYOR 2001.

- Mathematical Encounters, SOTOMAYOR 2018.

- On a list of Ordinary Differential Equations Problems, SOTOMAYOR 2019.

- Maurício Matos Peixoto, 1921-2019, SOTOMAYOR 2020-1.

- On M. M. Peixoto and the arrival of Structural Stability to Rio de Janeiro, 1955, SOTOMAYOR 2020-2.

- Reminiscences of a Mathematical Sojourn at San Marcos, 1959-62 and at IMPA, 1962, SOTOMAYOR 2020-3.

\section{Acknowledgements.}

The author is grateful to M. O. Sotomayor, C. P. Moromisato and L. F. Mello for their helpful style comments. He acknowledges the partial support of CNPq, PQ-SR307690/2016-4.

\section{Bibliography}

AHLFORS, L. Complex Analysis, McGraw-Hill, New York, 1953. APOSTOL, T. M. Análisis Matemático. Reverté, Segunda Ed., Barcelona, 1976. CIESIELSKA, D. and MALIGRANDA, L. Alfred Rosenblatt (1880-1947). PolishPeruvian Mathematician, Function Spaces XII, Banach Center Publications, Volume 119, 57-108, Institute of Mathematics, Polish Academy of Science, Warsaw, 2019. CODDINGTON, E. and LEVINSON, N. Theory of ordinary differential equations. New York, McGraw Hill, 1955.

HUREWICZ, W. Lectures on ordinary differential equations. New York, J. Wiley and Sons, 1958.

PEIXOTO, M. M. Structural Stability on two-dimensional manifolds, Topology, 1, pp. 101-120, 1962.

PEREIRA da Silva, C. Leopoldo Nachbin, um excelente matemático Brasileiro do século XX, Revista Brasileira de História da Matemática, Vol. 17, n. 34, pp. 73-81, 2017. PONTRYAGIN, L. S. Foundations of Combinatorial Topology, Dover Books on Mathematics, Paperback, April 22, 2015.

SEIFERT, H. and THRELFALL, W. Lecciones de Topología, Colección de Textos de Matemática Moderna I, Instituto Jorge Juan de Matemáticas, Madrid, 1951. SOTOMAYOR J. A Caderneta de Geometria, Revista do Professor de Matemática, vol. 21, pp.1-5, 1992. Reprinted in Revista da Olimpíada-IME-UFG, n. 3, pp. 100-104, 2002. An English translation can be found in: <https://www.researchgate.net/publication/327345 344_My_Geometry_Notebook>. 
SOTOMAYOR J. A few words on Maurício M. Peixoto on his $80^{\text {th }}$ birthday, Comput. Appl. Math., 20, 1, pp. 3-9, 2001.

SOTOMAYOR J. Mathematical encounters Notices of the International Congress of Chinese Mathematicians, Vol. 6, n. 2, pp. 94-98, 2018.

SOTOMAYOR J. On Maurício Matos Peixoto and his Mathematical Work, Lecture at the 10th Workshop on Dynamical Systems, São Carlos, July 2019. Available in: $<$ https://www.researchgate.net/publication/335128763>.

SOTOMAYOR J. On a list of ordinary differential equations problems, São Paulo Journal of Mathematical Sciences, DOI: 10.1007/s40863018-0110-3, 13(1), pp. 177-194, 2019-2.

SOTOMAYOR J., GARCIA, R. and MELLO, L. Sobre Maurício Matos Peixoto (19212019), Revista Matemática Universitária, Vol 1, pp. 1-22, 2020-1.

SOTOMAYOR J. On M. M. Peixoto and the arrival of Structural Stability to Rio de Janeiro, 1955. An. Acad. Bras. Cien. (2920), 2 92(1): e20191219, DOI 10.1590/0001376520-3765201920191219, 2020-2.

SOTOMAYOR J. Reminiscences of a Mathematical Sojourn at San Marcos, 1959-62 and at IMPA, 1962. Nexus Mathematicae, ISSN 2529-9824 e20007, 2020-3. In press. See also: https://www.researchgate.net/publication/327667534>.

WAERDEN, van der B. Modern Algebra, Frederick Ungar Publishing Co., New York, N. Y., 1949.

WILLMORE, T. J. Differential Geometry, Oxford Univ. Press, Glasgow, New York, 1959.

\section{Jorge Sotomayor}

Departamento de Matemática Aplicada - IME-SP campus de São Paulo - Brasil

E-mail: sotp@ime.usp.br 